\title{
Assay of lercanidipine hydrochloride in dosage forms using nucleophilic substitution reaction
}

THUTTAGUNTA MANIKYA SASTRY ${ }^{1, *}$ KARIPEDDI RAMAKRISHNA ${ }^{2}$

${ }^{1}$ Department of Chemistry

G V P College of Engineering

Visakhapatnam-530047, India

2 Department of Chemistry Institute of Science, GITAM University Visakhapatnam-530045, India

\begin{abstract}
A simple and sensitive spectrophotometric method has been developed for the assay of lercanidipine hydrochloride (LER) in bulk and in formulations. The method is based on the formation of coloured species between the drug and 1,2-naphthaquinone-4-sulphonic acid sodium salt (NQS) by means of nucleophilic substitution reaction. Absorbance was measured at $\lambda_{\max }=460 \mathrm{~nm}$. The method was analyzed statistically. The system obeyed the Beer's law in the range $20-100 \mu \mathrm{g} \mathrm{mL}^{-1}$. Molar absorptivity value was found to be $4.79 \times 10^{3} \mathrm{~L} \mathrm{~mol}^{-1} \mathrm{~cm}^{-1}$. Limits of detection and quantification were found to be as low as 0.04 and $0.13 \mu \mathrm{g} \mathrm{mL}^{-1}$. Precision (RSD, $0.4 \%$ ) and accuracy (recovery $99.2 \pm 0.6$ to $101.1 \pm 0.8 \%$ ) of the developed method were evaluated.
\end{abstract}

Keywords: spectrophotometry, lercanidipine hydrochloride, 1,2-naphthaquinone-4-sulphonic acid sodium salt (NQS)

Lercanidipine hydrochloride (LER) is chemically 2[(3,3-diphenylpropyl)(methyl)amino]-1,1-dimethylethyl methyl 2,6-dimethyl-4-(3-nitrophenyl)-1,4-dihydropyridine-3,5-dicarboxylate (Fig. 1). The drug is used as a calcium channel blocker in the treatment of hypertension (1). In literature, a number of analytical methods have been described for estimation of LER. These methods include HPLC $(2,3)$, TLC (4), voltammetry (5) and a few spectrophotometric methods (6-11). The authors have developed a simple, sensi-<smiles>COC(=O)C1=C(C)NC(C)=C(C(=O)OC(C)(C)CN(C)CCC(c2ccccc2)c2ccccc2)C1c1cccc([N+](=O)[O-])c1</smiles>

Fig. 1. Chemical structure of lercanidipine hydrochloride.

* Correspondence; e-mail: tmsastry@yahoo.com 
T. M. Sastry and K. Ramakrishna: Assay of lercanidipine hydrochloride in dosage forms using nucleophilic substitution reaction, Acta Pharm. 61 (2011) 457-463.

tive, accurate, reproducible, reliable and economical analytical method for estimation of LER in bulk drug and in formulations, useful for the laboratories with modest infrastructure.

\section{EXPERIMENTAL}

\section{Apparatus}

The measurements were made on a SL-177 model (Elico, India) visible spectrophotometer with $1 \mathrm{~cm}$ glass cells and on a UNICAM UV 500 spectrophotometer (Thermo Electron Corporation, UK). All pH measurements were made using a LI 120 digital pH meter (Elico, India).

\section{Reagents and materials}

All reagents and solvents were of analytical grade and all solutions were prepared in deionized water. Aqueous solutions of NQS (Loba, India, $0.5 \%, 1.92 \times 10^{-2} \mathrm{~mol} \mathrm{~L}^{-1}$ ), $\mathrm{NaOH}$ (Merck, India, $20 \%, 5 \mathrm{~mol} \mathrm{~L}^{-1}$ ), were used. The bulk drug lercanidipine hydrochloride (Sun Pharmaceutical Ind. Ltd., India) was selected for the study. Two formulations, Lerka (Sun Pharmaceutical Ind. Ltd., India) and Lerz (Glenmark, India) containing lercanidipine hydrochloride were purchased from local commercial sources. Tablets equivalent to $10 \mathrm{mg}$ of different batches of two formulations were selected.

About $100 \mathrm{mg}$ of bulk drug was dissolved in $10.0 \mathrm{~mL}$ methanol and reduced using the standard literature method (12). The reduced drug solution was diluted stepwise with distilled water to obtain the working standard solution of $400 \mu \mathrm{g} \mathrm{mL}^{-1}$ for the proposed method.

\section{Optimization of reaction conditions}

Optimum conditions for the method were established by varying one parameter at a time and keeping the others fixed and observing the effect produced on the absorbance of the colored species.

The effects of various parameters such as time, concentration of NQS and $\mathrm{NaOH}$ and solvent for final dilution on the stability and intensity of colored species were studied. Optimum conditions were as follows: $0.48-1.44 \times 10^{-3} \mathrm{~mol} \mathrm{~L}^{-1} \mathrm{NQS}, 0.75-1.25 \mathrm{~mol} \mathrm{~L}^{-1}$ $\mathrm{NaOH}$, temperature of $28 \pm 3{ }^{\circ} \mathrm{C}$ and the time required for color development within $8-15 \mathrm{~min}$ were found to be optimal. In the procedure, $0.5 \mathrm{~mL}\left(0.96 \times 10^{-3} \mathrm{~mol} \mathrm{~L}^{-1}\right)$ of NQS solution, $2.0 \mathrm{~mL}\left(1.0 \mathrm{~mol} \mathrm{~L}^{-1}\right)$ of $\mathrm{NaOH}$ solution, temperature of $28 \pm 3^{\circ} \mathrm{C}$ and $10 \mathrm{~min}$ required for maximum color development were found to be optimum conditions.

\section{General procedure}

Aliquots of the standard drug solution $\left(0.5-2.5 \mathrm{~mL}, 400 \mu \mathrm{g} \mathrm{mL}^{-1}\right)$ were placed in a series of calibrated tubes. Then, $0.5 \mathrm{~mL}$ of $1.92 \times 10^{-2} \mathrm{~mol} \mathrm{~L}^{-1} \mathrm{NQS}$ and $2.0 \mathrm{~mL}$ of $5 \mathrm{~mol} \mathrm{~L}^{-1}$ sodium hydroxide solutions were added to each tube and made up to the mark with dis- 
T. M. Sastry and K. Ramakrishna: Assay of lercanidipine hydrochloride in dosage forms using nucleophilic substitution reaction, Acta Pharm. 61 (2011) 457-463.

tilled water. The absorbance of colored species was measured at $460 \mathrm{~nm}$ against blank solution after keeping the solutions for $10 \mathrm{~min}$ at laboratory temperature. The stability of colored species was found to be $40 \mathrm{~min}$. Drug concentration was computed from the calibration graph.

Figures of merit for detection $(L O D)$ and limit of quantification $(L O Q)$ were established according to ICH guidelines (14) using the formula: $L O D=k \mathrm{SD}_{\mathrm{a}} / b$, where $k=$ 3.3, for $L O D$ and 10 for $L O Q . \mathrm{SD}_{\mathrm{a}}$ is the standard deviation of the intercept and $b$ is the slope of the calibration line.

The repeatability of the method was studied by repeating the method six times $(n=6)$. To study intra-day precision, the method was repeated six times a day. Similarly, the method was repeated on six consecutive days to determine inter-day precision.

The accuracy of the method was determined in terms of \% recovery of LER standard. Recovery studies were carried out by addition of standard drug solution at three different levels $(8,10,12 \mu \mathrm{g} \mathrm{mL}-1)$ to previously analyzed sample (tablet) solution.

Results obtained for $L O D, L O Q$, RSD and confidence interval are given in Table 1.

Table I. Optical characteristics, precision and accuracy of the proposed method

\begin{tabular}{|c|c|}
\hline Parameter & Value \\
\hline$\lambda_{\max }(\mathrm{nm})$ & 460 \\
\hline Beer's law limits $\left(\mu \mathrm{g} \mathrm{mL}^{-1}\right)$ & $20-100$ \\
\hline Limit of detection $\left(\mu \mathrm{g} \mathrm{mL}^{-1}\right)$ & 0.04 \\
\hline Limit of quantification $\left(\mu \mathrm{g} \mathrm{mL}^{-1}\right)$ & 0.13 \\
\hline Molar absorptivity $\left(\mathrm{L} \mathrm{mol}^{-1} \mathrm{~cm}^{-1}\right)$ & $4.79 \times 10^{3}$ \\
\hline \multicolumn{2}{|l|}{ Regression equation $(y=b c+a)$} \\
\hline Slope \pm SD & $7.4 \times 10^{-3} \pm 1.4 \times 10^{-5}$ \\
\hline Intercept $\pm \mathrm{SD}$ & $6.0 \times 10^{-4} \pm 9.4 \times 10^{-5}$ \\
\hline Correlation coefficient $(R)$ & 0.9999 \\
\hline \multicolumn{2}{|l|}{ Presicion (RSD, \%) ${ }^{\mathrm{a}}$} \\
\hline Intra-day & 0.4 \\
\hline Inter-day & 0.5 \\
\hline \multicolumn{2}{|l|}{ Range of error ${ }^{\mathrm{a}, \mathrm{b}}$} \\
\hline CL $(95 \%)\left(\mu g \mathrm{~mL}^{-1}\right)$ & \pm 0.44 \\
\hline CL $(99 \%)\left(\mu \mathrm{g} \mathrm{mL}^{-1}\right)$ & \pm 0.69 \\
\hline
\end{tabular}

a $n=6$.

b LER concentration: $60 \mu \mathrm{g} \mathrm{mL} \mathrm{m}^{-1}$.

$\mathrm{CL}$ - confidence limits.

\section{Assay of pharmaceutical formulations}

Tablets. - Since only two formulations, Lerka $10 \mathrm{mg}$ and Lerez $10 \mathrm{mg}$, were available as LER tablets, these formulations were collected from different batches and analyzed as 4 sets to verify the validity of the proposed method. Accurately weighed quantity of tablet 
powder equivalent to $100 \mathrm{mg}$ of LER was extracted with warm chloroform $(3 \times 25.0 \mathrm{~mL})$ and filtered. The combined extract was reduced using the standard literature method (12). The reduced drug solution was diluted stepwise with distilled water to obtain the working standard solution of concentration $400 \mu \mathrm{g} \mathrm{mL}^{-1}$ and appropriate aliquots of the solution were treated as mentioned above in the general procedure to test the validity of the method developed. The UV spectrophotometric method (13) was chosen as the reference method for ascertaining the accuracy of the proposed method.

\section{RESULTS AND DISCUSSION}

\section{Reaction mechanism}

In the NQS method, imino group of the drug replaces the sulphonic acid group of NQS. The most probable mechanism of nucleophilic substitution reaction of LER with NQS is presented in Scheme 1.<smiles>COC(=O)C1=C(C)NC(C)=C(C(=O)OC(C)(C)CN(C)CCC(c2ccccc2)c2ccccc2)C1c1cccc([N+](=O)[O-])c1</smiles>

Scheme 1. Scheme of the proposed reaction mechanism

\section{Method validation}

The developed method was validated as per ICH guidelines (14) for its linearity, precision, accuracy, and limit of detection.

Linearity and limit of detection/quantification. - Linearity was found in the concentration range $20-100 \mu \mathrm{g} \mathrm{mL}^{-1}$. Beer's law plots $(n=6)$ were linear with a correlation coefficient of 0.9999 . $L O D$ and $L O Q$ were found to be as low as 0.04 and $0.13 \mu \mathrm{g} \mathrm{mL}^{-1}$, respectively (Table I).

Precision. - The RSD values for both intra-day and inter-day precision are 0.4 and 0.5 $\%$, indicating that the proposed method is precise enough for the analysis of LER (Table 1).

Interference studies. - The extents of interference by various excipients that often accompany pharmaceutical formulations are tabulated in Table II. The high percentage of recovery mean value of $99.9 \%$ showed that excipients did not interfere with the proposed method. 
T. M. Sastry and K. Ramakrishna: Assay of lercanidipine hydrochloride in dosage forms using nucleophilic substitution reaction, Acta Pharm. 61 (2011) 457-463.

Table II. Assay of LER in the presence of excipients ${ }^{a}$

\begin{tabular}{lcc}
\hline Excipient & $\begin{array}{c}\text { Concentration } \\
\left(\mathrm{mg} \mathrm{mL}^{-1}\right)\end{array}$ & Recovery $(\%)^{\mathrm{b}}$ \\
\hline Talc & 3.0 & $99.8 \pm 0.2$ \\
Macrogol & 4.0 & $100.3 \pm 0.4$ \\
Polyvinyl alcohol & 5.0 & $99.9 \pm 0.6$ \\
Yellow iron oxide & 3.0 & $99.7 \pm 0.7$ \\
Titanium dioxide & 4.0 & $99.8 \pm 0.5$ \\
\hline
\end{tabular}

a Concentration of drug $40 \mu \mathrm{g} \mathrm{mL} \mathrm{m}^{-1}$.

b Mean \pm SD, $n=5$.

Table III. Assay of LER in pharmaceutical formulations

\begin{tabular}{ccccc}
\hline $\begin{array}{c}\text { Formulations } \\
\text { Tablet }\end{array}$ & $\begin{array}{c}\text { Mass per tablet } \\
(\mathrm{mg})\end{array}$ & $\begin{array}{c}\text { Drug found } \\
(\mathrm{mg})^{\mathrm{a}, \mathrm{b}}\end{array}$ & $\begin{array}{c}\text { Literature } \\
\text { method }(13)^{\mathrm{c}}\end{array}$ & $\begin{array}{c}\text { Recovery } \\
(\%)^{\mathrm{d}}\end{array}$ \\
\hline Lerka & 10 & $9.93 \pm 0.13$ & $9.96 \pm 0.10$ & $99.3 \pm 1.36$ \\
$($ Batch I) & & $\begin{array}{c}F=1.60 \\
t=0.33\end{array}$ & \\
& & $9.98 \pm 0.07$ & $10.05 \pm 0.13$ & $99.9 \pm 0.70$ \\
Lerka & 10 & $F=3.06$ & & \\
$($ Batch II) & & $t=2.09$ & & \\
& & $9.93 \pm 0.06$ & $9.92 \pm 0.12$ & \\
Lerez & 10 & $F=3.87$ & & \\
(Batch I) & & $t=0.33$ & \\
& & $10.11 \pm 0.08$ & \\
Lerez & 10 & $F=1.94$ & $9.92 \pm 0.12$ & \\
(Batch II) & & $t=1.68$ & & \\
& & &
\end{tabular}

a Mean \pm SD, $n=6$.

b Theoretical values at $95 \%$ confidence limit: $F=5.05, t=2.57$.

c Mean $\pm \mathrm{SD}, n=3$.

d $n=3$.

Accuracy and application of the proposed method. - Values of recovery \pm SD were found to be in the range of $99.2-101.1 \%(n=3)$, indicating that the proposed method is accurate for the analysis of the drug (Table III).

Application of the proposed method for the assay of pharmaceutical formulations was examined for tablets and the results were statistically compared with those obtained by the literature method (13). The results obtained by the proposed and UV spectrophotometric literature method for the formulations were compared by means of Student's $t$-test and $F$-test and it was found that both methods do not to differ significantly in precision and accuracy. The results are summarized in Table III. 
T. M. Sastry and K. Ramakrishna: Assay of lercanidipine hydrochloride in dosage forms using nucleophilic substitution reaction, Acta Pharm. 61 (2011) 457-463.

\section{CONCLUSIONS}

The proposed method is simple, sensitive, accurate and precise enough to be successfully adopted as an alternative to the existing spectrophotometric methods.

Acknowledgements. - One of the authors (TMS) is thankful to the Management of Gayatri Vidya Parishad College of Engineering, Visakhapatnam, for providing the facilities.

\section{REFERENCES}

1. K. J. McClellan and B. Jarvis, Lercanidipine: a review of its use in hypertension, Drugs 60 (2000) $1123-1140$.

2. S. Charde, L. Kumar and R. Saha, Development and validation of high-performance liquid chromatographic method for estimation of lercanidipine in rabbit serum, Anal. Lett. 40 (2007) 21282140; DOI: $10.1080 / 00032710701566636$.

3. I. Popovic, D. Ivanovic, M. Medenica, A. Malenovic and B. Jancic-Stojanovic, LC determination of lercanidipine and its impurities using dry lab software and experimental design procedures, Chromatographia 67 (2008) 449-454; DOI: 10.1365/s10337-008-0536-3.

4. P. V. Deore, A. A. Shirkhedkar and S. J. Surana, Simultaneous TLC-densitometric analysis of atenolol and lercanidipine hydrochloride in tablets, Acta Chromatogr. 20 (2008) 463-473; DOI: 10.1556/AChrom.20.2008.3.12.

5. Y. Altun, B. Uslu and S. A. Ozkan, Electroanalytical characteristics of lercanidipine and its voltametric determination in pharmaceuticals and human serum on boron-doped diamond electrode, Anal. Lett. 43 (2010) 1958-1975; DOI: 10.1080/00032711003687047.

6. V. Choudhari, M. V. Suryawanshi, H. R. Mahabal, G. S. Deshchougule, P. K. Bhalerao and S. B. Kuchekar, Simultaneous spectrophotometric estimation of atenolol and lercanidipine hydrochloride in combined dosage form by ratio derivative and dual wavelength method, Int. J. Pharm. Sci. Rev. Res. 3 (2010) 73-76.

7. K. S. Acharjya, S. Sahoo, K. K. Dash and M. M. Annapurna, Spectrophotometric determination of lercanidipine hydrochloride in pharmaceutical formulations, Int. J PharmTech Res. 2 (2010) 14311436.

8. G. Mubeen, D. S. Rao and K. Uvesh, Spectrophotometric method for determination of lercanidipine in tablets, Int. J. ChemTech. Res. 1 (2009) 1186-1188.

9. M. A. Abu El-Enin, D. R. El-Wasseef, D. T. El-Sherbiny and S. M. El-Ashry, Spectrophotometric determination of labetalol and lercanidipine in pure form and in pharmaceutical preparations using ferric-1,10-phenanthroline, Int. J. Biomed. Sci. 5 (2009) 261-266.

10. B. Sitaram, S. V. Saradhi and G. D. Rao, Novel spectrophotometric method for estimation of lercanidipine in pharmaceutical formulations, Int. J. Chem. Sci. 7 (2009) 2691-2694.

11. K. Tummuru, T. E. Divakar and C. S. P. Sastry, Spectrophotometric determination of some sulphur compounds and tryptophan with brucine and sodium metaperiodate, Analyst 109 (1984) 1105-1106; DOI: 10.1039/AN9840901105.

12. B. S. Furniss, A. J. Hannaford, P. W. G. Smith and A. R. Tatchell, Text Book of Practical Organic Chemistry, 5 th ed., Longman, Harlow 1994, p. 893.

13. R. Saha and S. Charde, Development and validation of ultraviolet spectrophotometric method for estimation of lercanidipine hydrochloride in bulk and formulations, AAPS J. 7 (S1) (2005) Abstr. M1001. 
T. M. Sastry and K. Ramakrishna: Assay of lercanidipine hydrochloride in dosage forms using nucleophilic substitution reaction, Acta Pharm. 61 (2011) 457-463.

14. International Conference on Harmonization of Technical Requirements for Registration of Pharmaceuticals for Human Use, ICH Harmonized Tripartite Guidance: Validation of Analytical Procedures: Text and Methodology Q2 (R1), ICH, London 2005.

\author{
$S A \check{Z} E T A K$
}

\title{
Određivanje lerkanidipin hidroklorida u ljekovitim oblicima reakcijom nukleofilne supstitucije
}

\author{
THUTTAGUNTA MANIKYA SASTRY i KARIPEDDI RAMAKRISHNA
}

Razvijena je osjetljiva spektrofotometrijska metoda za određivanje lerkanidipin hidroklorida (LER) u čistoj tvari i ljekovitim oblicima. Metoda se temelji na stvaranju obojenih produkata između ljekovite tvari i natrijeve soli 1,2-naftakinon-4-sulfonske kiseline (NQS) reakcijom nukleofilne supstitucije. Apsorbancija je mjerena pri $\lambda_{\max }=460 \mathrm{~nm}$. Metoda je obrađena statistički. Sistem je slijedio Beerov zakon u koncentracijskom području 20-100 mg mL-1. Molarni apsorpcijski koeficijent iznosio je 4,79 $\times 10^{3} \mathrm{~L} \mathrm{~mol}^{-1} \mathrm{~cm}^{-1}$, granice detekcije i kvantifikacije 0,04 , odnosno $0,13 \mathrm{mg} \mathrm{mL}^{-1}$. Nepreciznost $\mathrm{i}$ ispravnost metode iznosile su $0,4 \%$, odnosno $99,2 \pm 0,6$ do $101,1 \pm 0,8 \%$.

Ključne riječi: spektrofotometrija, lerkanidipin hidroklorid, natrijeva sol 1,2-naftakinon-4-sulfonske kiseline (NQS)

Department of Chemistry, G V P College of Engineering, Visakhapatnam-530047, India

Department of Chemistry, Institute of Science, GITAM University, Visakhapatnam-530045, India 